\title{
ANALYSIS OF RISK FACTORS FOR UNDERGROUND COAL GASIFICATION
}

\author{
Erika ŠKVAREKOVÁ, Marianna TOMAŠKOVÁ, Gabriel WITTENBERGER \\ Technical University of Košice \\ Štefan ZELENÁK \\ Hornonitrianske Bane Prievidza, a.s.
}

\begin{abstract}
:
The purpose of this article is to determine the environmental impacts of underground gasification on the population and to analyze the risk of underground coal gasification (UCG) activities using selected risk assessment methods. Coal gas is a regular part of coal deposits and its extraction also allows the use of coal deposits that cannot be extracted by traditional methods. These technologies bring both positive and negative aspects. The paper points out the risk analysis, hazard identification and assessment during the operation of UCG technology using a risk graph and a risk matrix. Identified risks to workers that cannot be reduced should be taken into consideration and appropriate safeguard should be used. For each risk, it is necessary to inform employees about regular education and training. From worldwide experience with this technology, it is possible to analyze risks in Slovakia. Actual gasification produces polluting gases such as carbon dioxide, carbon monoxide, hydrogen sulphide, hydrogen sulphide, nitrogen oxides, tar and ash, and creates a risk that may occur on and under the surface of the site depending on the geological and hydrogeological structure of the deposits. Possible measures to mitigate the adverse effects are proposed for the implementation of this technology. Coal is still one of the main domestic primary energy sources. Currently, only 5 out of 19 deposits in the Slovak Republic are used. Underground gasification could increase the use of Slovak coal and brown coal deposits.
\end{abstract}

Key words: analysis of risk, coal gas, environment, polluting gases, underground coal gasification

\author{
ABBREVIATIONS USED IN THE WORK \\ UCG - Underground Coal Gasification \\ CBM - Coal Bed Methan \\ UN - United Nations \\ EU - European Union \\ PAHs - Polycyclic Aromatic Hydrocarbons \\ BTEX - comprising benzene, toluene, ethylbenzene and $x y$ - \\ lene \\ HBP a.s. - Hornonitrianske bane Prievidza, a.s. - Slovakia's \\ largest mining company \\ BERG - Faculty of Mining, Ecology, Process Control and Ge- \\ otechnologies, Technical University of Košice \\ ENO - Nováky brown coal power plant, Slovakia
}

\section{INTRODUCTION}

Coal gas, an essential component of which is in particular methane, is produced during the process of coalification and is a natural part of every coal basin. The extraction of coal releases 60 to $80 \%$ of the gas bound in coal, which remains in the mining area, thus its exploitation is necessary for safety reasons. Gas is extracted from coal bed and is used for heating of mining operations, coal drying, power generation, and so on. Degassing is a normal part of coal mining. In the past, the extracted gas was regarded as waste, but currently, it is regarded as a by-product.

If the bed is not mined and there is a sufficient amount of gas, the gas from the seam is mined by the means of boreholes - a technology known as coal bed methane-CBM (or coal seam methane, coal seam gas). The success of mining depends on the natural permeability of the seam. In case of insufficient permeability, it must be artificially enhanced. The extracted gas normally contains more than $80 \%$ of methane. The gas composition, particularly the methane content, is decisive for its use. It is commonly used to produce electricity, but with a high content of methane, over $90 \%$, its use is the same as for natural gas and the gas is pumped into pipelines $[1,2]$.

UCG is also a technology for gas recovery in situ. The principle is based on the existence of at least two wells (often a series of wells), namely, injection and production wells, drilled into the coal bed. After ignition of the seam, the oxidizer is blown into the injection borehole and low to medium calorific gas is gathered by the production well. In the bearings, chemical reactions similar to those in conventional gasifying generators run. The extracted gas has a diverse quality which is dependent on the quality of coal, the type of oxidant and coping with the process $[3,4]$. 
The coal gas is a common part of the coal deposits. At the present extraction methods which also allow the use of coal deposits, which are not recoverable by conventional methods are also used. When obtaining gas from coal deposits, they could have several poisoning components that negatively affect the environment. Overall, it is possible to divide pollutant effects during underground coal gasification (UCG) and the extraction of methane from coal. We can divide negative effects into the impacts on the geological environment, water pollution in the gas treatment and pollution during drilling operations. Based on the multi-annual research on the UCG at the Faculty BERG, Technical University of Kosice, in Slovakia mining in Bane Cigel, company HBP, Inc. Prievidza is proposed for this technology [5].

The UCG is a transformation of heavy, liquid fuels into gaseous fuels which occurs in a coal bed. The gasification of coal under high temperatures causes decomposition of organic substance and tar, gas, cinder and ashes are produced. During the UCG controlled burning occurs under the ground in the coal seam [6, 7].

As already mentioned, at least two wells are injected into the coal layer (injection and production). Through the injection well, the layer is burned with gasification medium. By the second - production well the produced gas gets to the surface, see Figure $1[8,9]$.

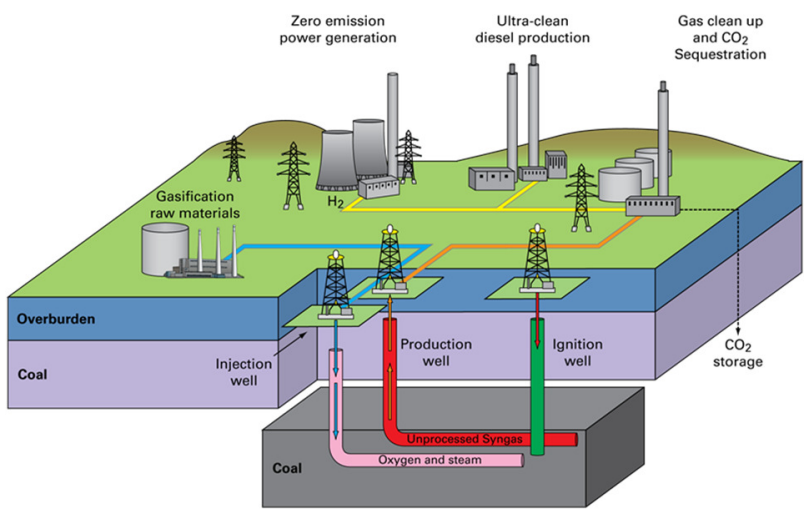

Fig. 1 Scheme of UCG technology for power generation Source: [5].

The main advantages of the techniques mentioned include reduction of two major greenhouse gases namely methane and carbon monoxide. All the technologies for capturing of methane are appreciated these days, as methane is emission gas which has up to 20-times greater effect in the atmosphere than $\mathrm{CO}_{2}$. Current research of CBM and UCG technologies is also aimed at consumption of $\mathrm{CO}_{2}$. In the case of UCG technology, no emission gas is consumed, but the idea of bringing UCG and CBM technologies together is interesting, as well as the possibility of $\mathrm{CO}_{2}$ storage in the incurred cavity after coal gasification [10, 11, 12].

UCG technology is used at the present in the People's Republic of China (the 1980s to present) and Australia (1990s to present). There are the largest UCG programs currently undergoing in China. The sixteen trials are carried out or currently operating since the late 1980s. For gasification are used abandoned galleries of coal mines. The injection and production wells are made by vertical boreholes drilled into the seam. To improve the production of hydrogen is used as a system of alteration air and steam injections.
Several companies are applying UCG syngas also due to government encouragement to diversify coal utilization and approach.

At the present UCG gas is used for ammonia and hydrogen production as well as for cooking and heating. Some announced plans are for a liquid fuel production facility fed by UCG with methanol and DME as products. The UCG centre at the China University of Mining and Technology, Beijing, is also testing UCG in abandoned coal mines. A technical centre for UCG has been set up in the University of Beijing, and technical exchange of information on UCG is taking place in the UK [13].

From 1997 through 2003 the Chinchilla project was made in Chinchilla, Queensland, Australia. It was the largest UCG project to date in the West part of Australia. Design and operation of the UCG plant were used with the help of company Ergo Exergy Technologies Inc., Canada (Ergo Exergy). The Chinchilla generated power production and liquid fuels production using gas-to-liquid technology, such as Fischer-Tropsch synthesis. The process plant is used to condition the gas to satisfy the strict requirements of the gas turbine [14].

More security is the goal of all decisions to increase the performance of a successful organization when designing manufacturing processes and managing human resources. Safe and functional complex systems can ensure the integrity of the quality circle so that the results will be a product of a quality that will allow its saleability [15].

The risk assessment should be carried out to identify potential operating hazards. Also, all employees must be trained and informed of the potential dangers of work [16].

When assessing the degree of threatening - as a negative phenomenon - it is necessary to determine the probability of its occurrence and to assess the extent of the possible consequences due to the effect of the negative phenomenon, i.e. to assess the risk.

It is then necessary to assess whether the risk is within an acceptable range. The manufacturer is obliged to:

- remove or minimize threats,

- design measures to control risks that cannot be eliminated.

Inform the user of residual risk machine: design the machine in such a way that even in the event of its malfunctioning, there are no risks in operation.

In the last years we can find significant progress in the evolution of underground gas technologies and it is connected with technology evolution such as more accomplished technologies in adjustment of underground coal gasification products, new methods of drilling, environmental thinking of the society, ratification of Kyoto Protocol and with it connected support of clean technologies within programs of EU and UN. In the case of an appropriate choice of underground gas deposit, it is important to know the storage, economical and geological conditions of the concrete coal deposit. Overall for correct consideration of underground coal gasification it is necessary to validate such factors as for example: depth of seam placement(bed, layer), thickness of the seam, dip of the seam, quantitative parameters such as heating qualities of the coal, ash content of coal, tectonic conditions of the seam and deposit, geomechanical characteristic of setup overlaying rock, permeability of the seam and setup, plastic 
qualities of the coal, thermic qualities of coal, presence of the gas in the deposit, characteristics of ashes. The above - mentioned parameters are necessary and they influence the position of certain generators, wanted works like drainage, rising permeability influences the process. Gravest influence has the underground coal gasification on underground waters. Service of the underground generator can violate inorganic balance and overall mineralization and also the stiffness of the underground water. From the generator's operation, some already mentioned substances can get into water for example hydrogen sulphide, carbon dioxide and tar. Due to high temperatures, it is obvious that surrounding rock formations will be heated as well as underground waters [17].

\section{MATERIAL AND METHODS}

Risk analysis - environmental impact of UCG on the population

While planning the main aims, that are supposed to be reached with the help of risk analysis, it is important to take into consideration these procedures [18]:

- selection of considered system and determination of its parameters,

- identification of danger,

- identification of threats,

- compliance of legal regulations,

- valuation of risk.

From the source point of view it is possible to decide risks to:

- deductive - derived from the statistical data according to injuries, accidents and other unwanted situations with analysis of its sources and results which happened,

- inductive - derived from the possibilities of what can happen, predictions of possibility and results of unwanted situation.

The main objective of risk assessment at work is to protect the health and safety of workers. Risk assessment helps to minimize possible damage to employees or the environment caused by work.

Risk is a combination of the probability of a negative event and its effect. The level of threat is a risk. The objective of hazard identification is to create a list of hazards, hazardous situations and events that allow the description of possible accident scenarios with regard to when and how the damage can occur in a hazardous situation. The technical standard TNI ISO/TR 14121-2 can be used for the risk assessment.

All standards dealing with a specific hazard or a specific type of machine are useful for identifying of risk and for anticipating of protective measures. A risk estimation tool may be selected and used to support the risk assessment process. Most of the available risk estimation tools use one of the following methods: risk matrix; risk graph; numerical score or quantified risk estimate.

There are also the mixed tools that use a combination of these methods.

There is used a risk matrix in this paper. Application of the risk matrix is as follows: for every identified hazardous situation, one category shall be selected for each parameter based on the definitions given above. The content of a cell intersecting the columns and rows, corresponding to each selected category, represents the estimated level of risk of the identified hazardous situation.

In the risk graph, the second method is to determine the risk index. The risk parameter (severity, probability of occurrence, etc.) shall be determined, whereby for each hazardous situation a final risk category or risk level shall be assigned to each parameter either by the word "large", "middle", small" or using numbers, for example from 1 to 6 , or letters from $A$ to $F$ in order to determine the risk index.

There are at disposal two basic approaches for the risk assessment:

- quantification of the quantifiable, i.e. measurable risk,

- grouping of the individual threats to create risk groups.

In order to estimate the probability in the form of a negative event, account shall be taken, in particular, of the following factors:

- type, frequency and duration of exposure,

- human factor,

- recognition of the existence of a hazard;

- technology and complexity of the dangerous situation,

- reliability of security measures, sustainability,

- level of maintenance activities,

- quality of control, inspection and testing activities,

- content and quality of operation technical documentation.

As with the frequency of negative phenomena, the effect depends on various factors such as:

- the relationship between the hazard and its effects;

- space and duration of exposure,

- a group of persons at risk,

- possibility to use protective measures e.g. personal protection equipment,

- quality of emergency or crisis plans/the better the plan, the lesser the effect of the negative phenomenon,

- the level of preparation of persons for behaviour during the existence of a negative phenomenon.

When assessing the risk, it is important to determine which persons, if any. groups of persons are exposed to threats i.e. for which persons it is necessary to assess the consequences of the negative effect.

While evaluating the frequency of dangers in the form of negative phenomena it is important to evaluate these factors [19]:

- type, frequency and duration of danger,

- human factor,

- recognition of danger existence,

- technology and complexity of the dangerous situation,

- reliability of security proceedings, maintainability,

- the rapidity of negative effect formation,

- level of maintenance procedures,

- quality of controlling, revision and testing activities,

- content and quality of operating documentation. 
As well as in the cases of frequent negative effect also its consequences are depending on different facts for example:

- the relation between the danger and its impacts,

- extent and time duration of danger,

- groups of people in danger,

- possibilities to use protecting proceedings for example use of personal protection,

- quality of emergency plans - higher the quality of the plan, minor the result of negative effect.

Preparation level of people presents during the existence of negative processes. The risk assessment by the selected methods is in Table 1 to 5 .

While reviewing risks it is important to determine which people of the group are exposed to the danger.

The quantitative judgment of the risks is done based on matrices, where the relation is strictly defined between probability, consequence and the risk.

Above mentioned point method recognizes four levels of risks in range of 20 points.

Level of the risk allows accepting concrete regulations which minimalize the risks.

UCG technology belongs to the so-called real coal technologies. During its processing, as well as during different production and mining operations adverse impact on the environment may occur.

When choosing the location for production, the possible contamination of the environment (water, soil, air), as well as the depth of the coal seam and filling of the bore which influence the subsidence, must be taken into account. In order to minimise the adverse impacts on the environment, it is necessary to ensure monitoring of groundwater and exploration and research analyses of the possible risks $[20,21,22]$.

This analysis has been widely studied. Analysis of the likely risks can be divided into impacts related to: drilling activities: e.g. noise, descend of the surroundings of the well, increased the traffic of heavier trucks.

The danger of UCG:

- carcinogenic waste (coal tar) contaminating water-bearing layers,

- the danger of underground explosions,

- gas emissions may come to the surface,

- subsidence may occur even after several years,

General effects:

- dust and air pollution at the time of production,

- populated areas are not suitable for research,

- delayed redevelopment of the area, the threat of uncontrolled extension of groundwater contamination $[23,24]$.

At present, the most significant Slovakian lignite deposits are in Novaky, Handlova and Cigel, located in the Upper Nitra Basin in the upper strata of Baden.

Lignitic deposits are developed on an area of about 70 $\mathrm{km}^{2}$. In the next part of the article risk of leakage of emissions of hazardous gases to the surface (e.g., missing pipes) as well as potential risks to the population from the others already mentioned influences while using the underground coal gasification technology are more particularised [25].
COMPARISON OF THE IMPACT OF MINING METHODS ON ENVIRONMENTAL COMPONENTS

The biggest problem in underground mining is damage to the whole ecosystem. Mining operations are less damaging to the landscape than surface mining. Generally speaking, deep mining and opencast mining are less damaging to the landscape than opencast mining. Generally speaking, underground and surface mining of coal has a negative impact on the landscape, agriculture, forestry, industrial areas.

Comparison of impacts of individual methods on the landscape is in the following Table.

Table 1

The Comparison of impacts of individual methods

on the landscape

\begin{tabular}{|c|c|c|c|}
\hline Impacts of lanscape & $\begin{array}{c}\text { Classical } \\
\text { mining }\end{array}$ & UCG & CBM \\
\hline $\begin{array}{l}\text { The changed country hinders its } \\
\text { use for agriculture, forestry }\end{array}$ & Yes & Yes & Not \\
\hline Change the look of the country & Yes & Not & Not \\
\hline $\begin{array}{l}\text { There is pollution of the air, } \\
\text { groundwater and surface water }\end{array}$ & Yes & Yes & Yes \\
\hline Noise & Yes & Yes & Yes \\
\hline $\begin{array}{l}\text { Generation of dust emissions by } \\
\text { caused by the transport }\end{array}$ & Yes & Yes & Yes \\
\hline Other emissions & Yes & Yes & Yes \\
\hline $\begin{array}{l}\text { Heaps of mining waste are pro- } \\
\text { duced }\end{array}$ & Yes & Not & Not \\
\hline $\begin{array}{l}\text { Wastes from coal and gas treat- } \\
\text { ment }\end{array}$ & Yes & Yes & Not \\
\hline Overflowing of utilized areas & Yes & Yes & Not \\
\hline $\begin{array}{l}\text { Impact on geology due to } \\
\text { changes in natural conditions }\end{array}$ & Yes & Yes & Yes \\
\hline $\begin{array}{l}\text { Storage contamination of sur- } \\
\text { face and ground water }\end{array}$ & Yes & Yes & Yes \\
\hline $\begin{array}{l}\text { Mining gas explosions and ex- } \\
\text { plosions }\end{array}$ & Yes & Yes & Not \\
\hline
\end{tabular}

Table 2

The Matrix of risk

\begin{tabular}{|c|c|c|c|}
\hline $\begin{array}{l}\text { Potential } \\
\text { range of } \\
\text { damage }\end{array}$ & \multirow{2}{*}{$\begin{array}{l}\text { Minor in- } \\
\text { jury or } \\
\text { health } \\
\text { threats }\end{array}$} & \multirow{2}{*}{$\begin{array}{cc}\text { Medium } & \text { Serious in- } \\
\text { level of in- } & \text { jury and } \\
\text { jury and } & \text { health } \\
\text { health } & \text { threats } \\
\text { threats } & \end{array}$} & \multirow{2}{*}{$\begin{array}{l}\text { Death Col- } \\
\text { lective in- } \\
\text { jury cata- } \\
\text { strophic re- } \\
\quad \text { sult }\end{array}$} \\
\hline $\begin{array}{l}\text { Probability } \\
\text { of damage }\end{array}$ & & & \\
\hline Very low & 1 & 2 & 4 \\
\hline Low & 2 & 4 & 5 \\
\hline Medium & 3 & 5 & 6 \\
\hline High & 4 & 6 & 7 \\
\hline Presumption & Judgment & \multicolumn{2}{|c|}{ Decription and lowering of risks } \\
\hline $1-2$ & Low & \multicolumn{2}{|c|}{ Acceptable risk } \\
\hline $3-4$ & Important & \multicolumn{2}{|c|}{ Inevitable to lower risk } \\
\hline $5-7$ & High & \multicolumn{2}{|c|}{$\begin{array}{l}\text { Immediate acceptance of proceed- } \\
\text { ings to lower the risk }\end{array}$} \\
\hline
\end{tabular}

Source: $[26,27]$. 
Table 3

The initial risk analysis UCG from drilling activity, with the help of Graph of risk and the Matrix of risk

\begin{tabular}{|c|c|c|c|c|c|c|c|c|c|c|}
\hline \multicolumn{2}{|c|}{ Activity } & \multicolumn{4}{|c|}{ Unsafe conditions } & \multicolumn{5}{|c|}{ Risk Estimation - Calculation of risk index } \\
\hline$\frac{c}{\circ}$ & 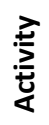 & 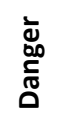 & $\begin{array}{l}\text { Hazardous } \\
\text { situation }\end{array}$ & $\begin{array}{c}\text { Dangerous } \\
\text { event }\end{array}$ & Potentional damage & $\begin{array}{c}\text { Severity } \\
\text { S1/S2 }\end{array}$ & $\begin{array}{c}\text { Frequency } \\
\text { F1/F2 }\end{array}$ & $\begin{array}{l}\text { Probability } \\
\text { formation } \\
01 / 02 / 03\end{array}$ & \begin{tabular}{|c|} 
Possible pre- \\
vention \\
A1/A2
\end{tabular} & $\begin{array}{l}\text { Index } \\
\text { of risks } \\
1-6\end{array}$ \\
\hline 1.0 & \multirow{3}{*}{ ত্ } & \multirow{3}{*}{ 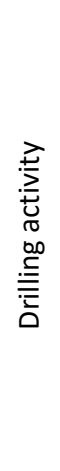 } & Noise & $\begin{array}{l}\text { Crossing } \\
\text { accessible } \\
\text { rate }\end{array}$ & Injury to persons & $\mathrm{S} 1 ; 2^{*}$ & $\mathrm{~F} 1 ; 2^{*}$ & $01 ; 2^{*}$ & $\mathrm{~A} 1 ; 2^{*}$ & $1 ; 3^{*}$ \\
\hline 1.1 & & & $\begin{array}{l}\text { All through sur- } \\
\text { rounding wells }\end{array}$ & \begin{tabular}{|l} 
Decrease \\
with \\
subsequent \\
overflow \\
area \\
\end{tabular} & $\begin{array}{l}\text { Depreciation area, } \\
\text { nearby buildings, } \\
\text { grievous bodily } \\
\text { harm people, death } \\
\text { to peaple }\end{array}$ & $\mathrm{S} 2 ; 3^{*}$ & $\mathrm{~F} 1 ; 3^{*}$ & $02 ; 3^{*}$ & $\mathrm{~A} 1 ; 3^{*}$ & $2 ; 5^{*}$ \\
\hline 1.2 & & & $\begin{array}{l}\text { Increased } \\
\text { transport of heav- } \\
\text { ier vehicles rental }\end{array}$ & $\begin{array}{l}\text { Increase } \\
\text { in the } \\
\text { frequency } \\
\text { of trucks }\end{array}$ & Depreciation area & $\mathrm{S} 1 ; 2^{*}$ & $\mathrm{~F} 1 ; 2^{*}$ & $02 ; 2^{*}$ & $\mathrm{~A} 1 ; 2^{*}$ & $1 ; 3^{*}$ \\
\hline
\end{tabular}

* valuation, with the help of the Matrix of risk

Source: $[18,26,27]$.

Table 4

The initial risk analysis from the operation of UCG technology with the help of Graph of risk and the Matrix of risk

\begin{tabular}{|c|c|c|c|c|c|c|c|c|c|c|}
\hline \multicolumn{2}{|c|}{ Activity } & \multicolumn{4}{|c|}{ Unsafe conditions } & \multicolumn{5}{|c|}{ Risk Estimation - Calculation of risk index } \\
\hline$\frac{}{\frac{5}{H}}$ & 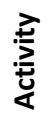 & 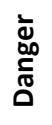 & $\begin{array}{c}\text { Hazardous situa- } \\
\text { tion }\end{array}$ & $\begin{array}{l}\text { Dangerous } \\
\text { event }\end{array}$ & Potentional damage & $\begin{array}{c}\text { Severity } \\
\text { S1/S2 }\end{array}$ & $\begin{array}{l}\text { Frequency } \\
\text { F1/F2 }\end{array}$ & $\begin{array}{l}\text { Probability } \\
\text { formation } \\
01 / 02 / 03\end{array}$ & $\begin{array}{c}\text { Possible } \\
\text { prevention } \\
\text { A1/A2 }\end{array}$ & $\begin{array}{l}\text { Index of } \\
\text { risks } \\
1-6\end{array}$ \\
\hline 2.0 & & ठे० & $\begin{array}{l}\text { Danger } \\
\text { of uncontrolled un- } \\
\text { derground } \\
\text { coal gasification }\end{array}$ & \begin{tabular}{|l|} 
Escape \\
danger. \\
Gas to the \\
surface, \\
tar free move- \\
ment into \\
ground water, \\
undegroud ex- \\
plosions
\end{tabular} & $\begin{array}{l}\text { Injury and possible } \\
\text { death and people } \\
\text { living near the gasi- } \\
\text { fier }\end{array}$ & $\mathrm{S} 2 ; 3^{*}$ & $\mathrm{~F} 2 ; 3^{*}$ & $02 ; 2^{*}$ & $\mathrm{~A} 1 ; 2^{*}$ & $4 ; 4^{*}$ \\
\hline 2.1 & ভ্ড & 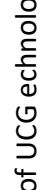 & \begin{tabular}{|l|} 
Carcinogenic \\
waste/coal \\
tar/contaminating \\
aquifers
\end{tabular} & $\begin{array}{l}\text { Uncontrolled } \\
\text { leakage of tar }\end{array}$ & $\begin{array}{l}\text { Depreciation area } \\
\text { for ground water } \\
\text { contamination, in- } \\
\text { jury to persons, } \\
\text { death to persons }\end{array}$ & $\mathrm{S} 2 ; 3^{*}$ & $\mathrm{~F} 2 ; 3^{*}$ & $\mathrm{O} 2 ; 3^{*}$ & $\mathrm{~A} 2 ; 3^{*}$ & $5 ; 5^{*}$ \\
\hline 2.2 & & 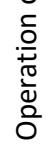 & $\begin{array}{l}\text { Danger of under- } \\
\text { ground explosions }\end{array}$ & $\begin{array}{l}\text { Explosion-ac- } \\
\text { cident }\end{array}$ & $\begin{array}{l}\text { Injury and possible } \\
\text { death and people } \\
\text { living near the gasi- } \\
\text { fier }\end{array}$ & $\mathrm{S} 2 ; 4^{*}$ & $\mathrm{~F} 2 ; 4^{*}$ & $02 ; 2^{*}$ & $A 1 ; 2^{*}$ & $4 ; 5^{*}$ \\
\hline 2.3 & & & $\begin{array}{l}\text { Gas emissions may } \\
\text { come to the sur- } \\
\text { face } / \text { eg. } \mathrm{CO}, \mathrm{CO}_{2} \text {, } \\
\mathrm{CH}_{4} /\end{array}$ & Crash & $\begin{array}{l}\text { Injury and possible } \\
\text { death and people } \\
\text { living near the gasi- } \\
\text { fier }\end{array}$ & $\mathrm{S} 2 ; 3^{*}$ & $\mathrm{~F} 2 ; 3^{*}$ & $02 ; 2^{*}$ & $\mathrm{~A} 2 ; 2^{*}$ & $5 ; 4^{*}$ \\
\hline 2.4 & & & $\begin{array}{l}\text { Subsidence may } \\
\text { occur even after } \\
\text { several years }\end{array}$ & $\begin{array}{l}\text { Declines } \\
\text { buildings }\end{array}$ & $\begin{array}{l}\text { Injury and possibly } \\
\text { death in people liv- } \\
\text { ing near the gasifier }\end{array}$ & S2; $3^{*}$ & $\mathrm{~F} 2 ; 3^{*}$ & $02 ; 2^{*}$ & $\mathrm{~A} 2 ; 2^{*}$ & $5 ; 4^{*}$ \\
\hline
\end{tabular}

* valuation, with the help of Matrix of risk

Source: $[19,26,27]$. 
The initial risk analysis from general impacts with the help of Graph of risk and the Matrix of risk

\begin{tabular}{|c|c|c|c|c|c|c|c|c|c|c|}
\hline \multicolumn{2}{|c|}{ Activity } & \multicolumn{4}{|c|}{ Unsafe conditions } & \multicolumn{5}{|c|}{ Risk Estimation - Calculation of risk index } \\
\hline  & 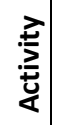 &  & $\begin{array}{c}\text { Hazardous situa- } \\
\text { tion }\end{array}$ & $\begin{array}{l}\text { Dangerous } \\
\text { event }\end{array}$ & $\begin{array}{l}\text { Potentional } \\
\text { damage }\end{array}$ & $\begin{array}{l}\text { Severity } \\
\text { S1/S2 }\end{array}$ & $\begin{array}{l}\text { Frequency } \\
\text { F1/F2 }\end{array}$ & $\begin{array}{c}\text { Probability for- } \\
\text { mation } \\
01 / 02 / 03\end{array}$ & $\begin{array}{c}\text { Possible preven- } \\
\text { tion } \\
\text { A1/A2 }\end{array}$ & $\begin{array}{c}\text { Index } \\
\text { of risks } \\
1-6\end{array}$ \\
\hline 3.0 & \multirow{3}{*}{ ড্ডে } & \multirow{3}{*}{ 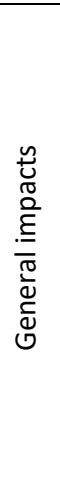 } & $\begin{array}{l}\text { Dust and air } \\
\text { pollution } \\
\text { at the time } \\
\text { of production }\end{array}$ & $\begin{array}{l}\text { Long-term } \\
\text { pollution }\end{array}$ & $\begin{array}{l}\text { respiratory } \\
\text { diseases }\end{array}$ & $\mathrm{S} 1 ; 2^{*}$ & $\mathrm{~F} 1 ; 2^{*}$ & $01 ; 2^{*}$ & $\mathrm{~A} 1 ; 2^{*}$ & $1 ; 3^{*}$ \\
\hline 3.1 & & & $\begin{array}{l}\text { Populated areas } \\
\text { are not suitable } \\
\text { for research }\end{array}$ & $\begin{array}{l}\text { Long-term } \\
\text { restriction }\end{array}$ & $\begin{array}{l}\text { Scarcity } \\
\text { of movement }\end{array}$ & $\mathrm{S} 1 ; 3^{*}$ & $\mathrm{~F} 1 ; 3^{*}$ & $01 ; 3^{*}$ & $A 1 ; 3^{*}$ & $1 ; 5^{*}$ \\
\hline 3.2 & & & $\begin{array}{l}\text { Late remediation, } \\
\text { the threat of un- } \\
\text { controlled pollu- } \\
\text { tion of groundwa- } \\
\text { ter }\end{array}$ & $\begin{array}{l}\text { Occurrence } \\
\text { of hazardous } \\
\text { substances } \\
\text { in drinking } \\
\text { water }\end{array}$ & $\begin{array}{l}\text { Persistent ef- } \\
\text { fects, poison- } \\
\text { ing, death }\end{array}$ & $\mathrm{S} 2 ; 4^{*}$ & $\mathrm{~F} 2 ; 4^{*}$ & $02 ; 3^{*}$ & $A 1 ; 3^{*}$ & $4 ; 6^{*}$ \\
\hline
\end{tabular}

* valuation, with the help of Matrix of risk

Legend for tables:

S-severity of the damage, slight injury S1, S2-serious injury, including death, F-frequency and / or duration of exposure to threat-F1 twice or less per shift, F2-more than twice per shift, $O$ - The likelihood of a hazardous event, O1-proven, mature technology, O2-in the last two years has seen the technical problems O3-technical failure occurs regularly, every six months or more frequently, A-Possibility of avoiding damage, or limit the damage A1-possible under certain conditions, A2 - impossible, 1-2 Lowest priority activities, 3-4 medium priority activities, 5-6 highest priority activities

Source: $[26,27,28]$.

\section{ANALYSIS AND DISCUSSION}

\section{Evaluation of risk analysis}

The territory of a listed UCG unit in previously implemented projects to Mine Cigel, VII. Mining section.

Mining activity has a real impact on the environment as well as the morphology of the whole region in the area of interest. Prievidza is one of the most industrialised and urbanised regions of Slovakia with a predominance of fuel and energy, mining and chemical industries. The District is among the districts with the highest pollution in Slovakia. Part of the area is included in one of the eight polluted areas of Slovakia.

Economically most major-strongest are the three lignite mines - Novaky, Handlova and Cigel located in the Upper Nitra bearing.

Domestic use of coal is around 1.8. 10 $-\mathrm{Mg}$ per year. Consumption of domestic lignite mining is about the same and is closely linked to the security of energy supply, particularly electricity and heat in the region (power Novak (ENO). Overall coal consumption in Slovakia in recent years ranks from $8.2 .10^{5}$ to $9.5 .10^{5} \mathrm{Mg}$, of which most were imported from abroad. Sustainable development of coal mining in the next period in Slovakia is closely related to material reserves, new mining technologies and the Government of the commitments of general economic interest. The security of energy supplies is important, of course, all in the context of international obligations, in particular, those relating to climate change and the environment, especially air protection [29].

According to Tables 2 to 4, where both methods are compared, this is a high risk for 2.1. Threats derived from the operation of UCG, 2.3. Gas emission, the gas which can get on the surface, 3.1. Inhabited areas are not suitable for investigations, according to Table 2: 1.1 Founder in surroundings of boreholes, 2.1 Cancerous waste, 2.2 Possibility of underground explosions.

\section{RISK ANALYSIS TO SLOVAK CONDITIONS}

Based on the surveyed worldwide experience in this technology it is possible to analyse the risks to Slovak conditions:

1) change in the morphology of the terrain (due to the creation of underground cavities burnout):

- spaces filled with the ashes may be under the influence weight of the overlying rocks buried or severe twist wells, [30].

2) pollution of the ground, contamination of the ground can be caused by:

- leaking gases,

- aromatic hydrocarbon,

- volatile combustible solid residues and, in the case where the surrounding rock was leaking [31].

In the actual gasification polluting gases arise such as:

- carbon dioxide,

- carbon monoxide,

- hydrogen sulphide (hydrogen sulphide),

- carbon disulphide,

- nitrogen oxides,

- mercaptans.

These volatile compounds have high toxicity and strong smell. By examining the core components of coal from the mine Cigel' arsenic was pointed out that was found in the ashes due to the presence of pyrite $-\mathrm{FeS}_{2}$, realgar $-\mathrm{As}_{4} \mathrm{~S}_{4}$, arsenopyrite-FeAsS and orpiment - $\mathrm{As}_{2} \mathrm{~S}_{3}$ in the coal substance. Tar and ash were analysed in an accredited laboratory to verify the presence of pollutants, such as:

- PAHs

- volatile matter BTEX (benzene, toluene, xylene), 
- solid residues and trace elements of heavy metals ( $\mathrm{Fe}$, $\mathrm{Mn}, \mathrm{Mg}, \mathrm{Ca}, \mathrm{Ti}, \mathrm{P}, \mathrm{As}$, etc.).

The Environmental Protection Agency (U.S. EPA) has determined the 16 PAHs which were located in the tar. Hydrocarbons are following: acenaphthene, phenanthrene, anthracene, fluoranthene, pyrene, benzo (a) anthracene, chrysene, benzo (b, k) fluoranthene, benzo (a) pyrene, dibenzo $(a, h)$ anthracene, benzo $(g, h, i)$ perylene, indeno $(1,2,3-c, d)$ pyrene. Samples contained other pollutants and volatile compounds: TOC, TPH-IR and BTEX $[32,33]$. After conversion and during the production of tar 31.8 I/650 tonnes of coal gasification represents the total output of tar at 9800 litres. Such tar contamination poses a threat to the rock environment. Use of this product is expected after gasification in the chemical industry, and therefore the majority of its components must drained from the generator, preferably in gaseous form.

Process management is needed to ensure that the condensation of gaseous components has taken place in the generator. As long as this requirement is met it is also necessary to reduce the risk of contamination of the ground. Despite the relatively large stability of the aromatic ring, a degradation of PAHs may occur in the environment. In aqueous systems, microbial degradation under aerobic conditions plays a significant role in the decomposition of $\mathrm{PAH}$, whereas under anaerobic conditions the degradation takes place extremely slowly. Some PAHs are partially or completely degraded by some types of bacteria and fungi [16].

Risks that may occur on the surface and below the surface in a given locality, depending on geological and hydrogeological structures bearings, are divided into three cases:

- the generator and its surroundings remain contaminants in variable form,

- contaminants in the generator and its environs enter the water,

- there are communication paths for the movement of contaminants out of the generator.

After analysing the assumptions affecting the geological environment, in the specific causes following partial conclusions may be done:

- it is necessary to focus on reducing the number of contaminants left in the generator,

- after the termination of the generators activities to lessen the content of residual pollutants,

- carrying out injection space generator in such a way as to effect adjustment of contaminant source (for example, physical-chemical) to limit the mobility of contaminants and their ability to transfer the transport medium [34].

\section{OPTIONS FOR RISK MINIMIZATION}

For the implementation of this technology possible measures to mitigate the adverse effects of this business are proposed and in the case of potential contamination is recommended:

- before disposal wells and underground generator cavity are flushed by water, to minimise possible pollution and water in the area resulting cavity,
- contaminated water can be cleaned in the surface water treatment plant,

- when the process requires long-term monitoring of the resulting cavity and its surroundings,

- for drilling and filling cavities after gasification principle of reuse of waste for solidification and stabilisation was proposed. Due to the usability of solidification for mining conditions hardening methods are the most suitable case, abroad used already for disposal and recovery of waste containing mainly heavy metals. It is a matter of physical and chemical treatment of waste through homogenization with suitable components to prevent the release of pollutants into the natural environment [5].

Technical failure factor can be reduced by:

- the quality of withdrawals,

- modernization of technical equipment,

- compliance with preventive examinations scheduled time,

- maintenance and repair of equipment.

The risk of human error probability can be reduced by:

- compliance with operating procedures,

- personal use of work equipment and specialisations.

Based on a comprehensive assessment of the proposed action, it can be stated that this technology could, in the case of an accident, bring risk to areas associated with significant damage to health or the environment (groundwater and thermal springs in the vicinity of Bojnice), because the bearing is located in proximity to residential zones.

The method CEI was in the literature [10] set index for chemical hazards for the storage and transport of carbon monoxide in underground gasification technology for surrounding villages (Sebedrazie and Cigel).

\section{CONCLUSION}

Based on the multi-annual research on the UCG at the Faculty BERG, Technical University of Kosice, in Slovakia for this technology mining in Bane Cigel, company HBP, Inc. Prievidza is proposed. In the case of UCG technology in Slovakia it refers to pollution of air, water, soil and waste anticipated. We reviewed health risks, assessing the expected impacts in terms of their importance and the time course of action context, which can cause effects in the light of the current state of the environment.

Coal is still one of the major domestic primary sources of energy. Currently, only 5 of 19 bearings are used. Underground gasification could help to increase the use of Slovak deposits of coal and lignite. Environmental aspects are currently a very important factor when considering most of the technologies. Awareness of the pros and cons of the technologies in the environmental field is important for comprehensive assessment and review of potential risks.

An essential prerequisite for ensuring safety and health at work of employees in the exercise of their activity is risk analysis, which according to the Act No. 124/2006 of the National Council of the Slovak Republic, call the duty of every employer. The objective of risk analysis is the identification and assessment of hazards by which the staff is threatened in their work. Identified risks 
threatening the employees at work need to be corrected. Those that cannot be reduced, it is necessary to accept them and provide for appropriate protective measures. Of any risks, it is a need to inform employees demonstrably in regular education and training activities.

The results of initial analyses are shown in Tables 2, 3, 4 where they are evaluated according to the Graph of risk ( $1^{\text {st }}$ method), and Matrix of risk, see Table $1,\left(2^{\text {nd }}\right.$ method). Priority risk is illustrated in colour according to the degree of severity and priority needs of its reduction.

The proposed mitigation measures for each risk activities are set out in part Evaluation of risk analysis These measures do not eliminate the risks identified, but their implementation and compliance with the possible risks can be reduced to an acceptable level and thus prevent serious threats to the health and lives of workers and people living near the gasifier.

\section{ACKNOWLEGEMENT}

This contribution is the result of the project VEGA no. 1/0121/18 Developing Methods for Implementing and Verifying Comprehensive Security Solutions in Smart Factory as part of Industry Strategy 4.0 APVV-15-0351 Development and application of risk management models under technological process conditions in line with Industry (Industry) 4.0.

\section{REFERENCES}

[1] Burchart-Korol D., Krawczyk, P., Czaplicka-Kolarz, K. Ecoefficiency of underground coal gasification (UCG) for electricity production, FUEL, 2016, 173.

[2] Białecka B. Estimation of coal reserves for UCG in the upper silesian coal Basin. Natural Resources Research. 17, (1), 2008, 21-28.

[3] Brown K. M. In situ coal gasification. An emerging technology, Journal Am. Soc. Min. Reclam, 2012, (1)

[4] Mocek, P.; Pieszczek, M.; Swiadrowski, J.; Kapusta, K.; Wiatowski, M.; Stanczyk, K. Pilot-scale underground coal gasification (UCG) experiment in an operating Mine "Wieczorek" in Poland. Energy 2016, 111, 313-321.

[5] Sasvari T., Blištáanová M., Kondela J., Pinka J., Sidorová M., Škvareková E., Vizi L., Wittenberger G. Possibility of obtaining energy of gas from coal deposits. ES TU FBERG, 2007.

[6] Uppal A. A., Bhatti A. I., Aamir E., Samar R., Khan S. A. Control oriented modeling and optimization of one dimensional packed bed model of underground coal gasification. Journal of Process Control, Elsevier, 2014, 1,(24).

[7] Doucet D., Perkins G., Ulbrich, A., du Toit, E. Production of power using underground coal gasification, Energy Sources, Part A: Recovery, Utilization and Environmental Effects 2016, 38(24), 3653-3660.

[8] Lin X., Zuotang W., Wengang H., Guojun K., Xuefeng L., Peng, Z. Jianhua W. Temperature field distribution of burnt surrounding rock in UCG stope. International Journal of Mining Science and Technology, Elsevier, 2014, 24.

[9] Bhutto A. W., Bazmi A. A., Zahedi G.Underground coal gasification: From fundamentals to applications, Progress in Energy and Combustion Science, Pergamon, 2013, 1(39).

[10] Škvareková, E., Bakalár, T. Impact of gas extraction from coal deposits on the environment, SGEM, Sofia, STEF92 Technology Ltd., 2011, 795-800.

[11] Schiffrin D.J. The feasibility of in situ geological sequestration of supercritical carbon dioxide coupled to underground coal gasification, Energy and Environmental Science,
2016, 8(8), 2330-2340.

[12] Khan Md.,M., Joseph P. Mmbaga Ahad S. Shirazi, Qingzia Liu and Rajender Gupta. Modelling Underground Coal Gasification. Energies, 2015, 8(11), 12603-12668; https://doi.org/10.3390/en81112331

[13] Ding T., Ning Y., Zhang Y. The Contribution of China's Outward Foreign Direct Investment (OFDI) to the Reduction of Global $\mathrm{CO}_{2}$ Emissions.

[14] Burton E., Friedmann J., Upadhye R. Best Practices in Underground Coal Gasification. Lawrence Livermore National Laboratory, 2014.

[15] Oravec M., Balážiková M., Tomašková M. Influence of the working environment on safety and health protection at work and of the employees in an office space, Science Business Society, 2018,3(3).

[16] Pačaiová H., Markulik Š., Turisová R., Nagyová A. How to Build Risk-based Thinking Methodology Based on Process Approach. Faculty of Mechanical Engineering, the Technical University in Košice, 2018, 22 , (1).

[17] Zelenák Š., Škvareková E. Underground gasification of coal in mining area Cígel', geological and hydrogeological conditions, Odpadové forum, OZE, Praha, 2012.

[18] Sinay J., Pačaiová, H. Integration model of safety and security as a part of integrated safety, Future Security, Freiburg, Fraunhofer, 2016.

[19] Sinay J. Training, Consulting and Certification Center for risk management in machine safety, occupational health and safety and environmental risks. Potential and services of USP Technicom for efficient development of entrepreneurship and research collaboration with industry, Elfa Košice, 2015.

[20] Dubiński J., Turek M. Mining problems of underground coal gasification-Reflections based on experience gained in experiment conducted in KHW S.A. Wieczorek coal mine, Mining Science, 2016, 23, 7-20.

[21] Čech J., Šofranko M. Economic Projection and Evaluation of Mining Venture, E \& M Economics and Management, Liberec, Czech Republic, 2018, 21,(2).

[22] Group Authors. EEA, European Environment Agency. Renewable Energy in Europe 2017. Recent Growth and Knock - on Effects EEA Report No 3/2017, Publications Office of the European Union, Luxembourg, 2017.

[23] Ekneligoda T.C., Marshall A.M. A coupled thermal-mechanical numerical model of underground coal gasification (UCG) including spontaneous coal combustion and its effects, International Journal of Coal Geology 2018, 199, 3138.

[24] Sidorova M, Beysembayev K., M, Shmanov M. N., Kanat K. M. and Aizat M., E. Plastic Flow Modeling in Rock Fracture, Acta Montanistica Slovaca, 2018, 23,(4).

[25] Kačur J., Durdán M., Laciak M.,Flegner P. Impact analysis of the oxidant in the process of underground coal gasification. Measurement, Elsevier, 2014, 1,( 51).

[26] Act. 124/2006 NR SR on safety and health at work and on amendments to certain laws.

[27] Bakalár, T., Pavolova H., Khouri S., Pristášová I. Influence of additives on decrease of temperature of slag flow from energy coal in wet bottom boiler, Metalurgija, 2017, 3-4 (56).

[28] Tomašková, M. Risk assessment and their quantification, 2013, 3, (11).

[29] Kapusta K., Wiatowski M., Stanczyk K. An experimental exsitu study of the suitability of a high moisture ortho-lignite for underground coal gasification (UCG) process, FUEL, 2016, 179. 
[30] Tianhong D., Zuotang W., Limin Z., Dongdong L. Gas production strategy of underground coal gasification based on multiple gas sources, Scientific World Journal, 2016.

[31] Hammond G. P.,Waldron, R. (): Risk assessment of UK electricity supply in a rapidly evolving energy sector, Proceedings of the institution of mechanical engineers Parta. Journal of Power and Energy, 2008, 222, ( A7), Special Issue.

[32] Laciak, M., Kostúr, K., Durdán, M., Kačur, J., Flegner, P. The analysis of the underground coal gasification in experimental equipment, Energy, 2016, 114, 332-343.

\section{Erika Škvareková}

ORCID ID: 0000-0003-2314-5686

Technical University of Košice,

Faculty of Mining, Ecologz, Process Control and Geotechnologies Institute of Earth Resources

Letná 9, 04000 Košice, Slovak Republic

e-mail: erika.skvarekova@tuke.sk

\section{Marianna Tomašková}

ORCID ID: 0000-0001-6281-1501

Technical University of Košice,

Faculty of Mechanical Engineering,

Department of safety and quality production

Letná 9, 04000 Košice, Slovak Republic

e-mail: marianna.tomaskova@tuke.sk

\section{Gabriel Wittenberger}

ORCID ID: 0000-0001-9742-7956

Technical University of Košice,

Faculty of Mining, Ecologz, Process Control and Geotechnologies Institute of Earth Resources

Letná 9, 04000 Košice, Slovak Republic

e-mail: gabriel.wittenberger@tuke.sk

\section{Štefan Zelenák}

ORCID ID: 0000-0002-2872-2473

Hornonitrianske Bane Prievidza, a.s.

Matice slovenskej 10, 97101 Prievidza, Slovak Republic

e-mail: szelenak@hbp.sk
[33] Perkins, G. Underground coal gasification - Part I: Field demonstrations and process performance, Progress in Energy and Combustion Science, 2018, 67, 158-187.

[34] Taušová, M., Rybárová J., Khouri S. Financial analysis, as a marketing tool in the process of raising awareness on renewable energy, Acta Montanistica Slovaca, 2007, 12, http://actamont.tuke.sk/. 